Copyright: (C) 2020, Seva Demiroz. This is an open access article distributed in accordance with the terms of the Creative Commons Attribution (CC BY NC ND 2.0) License.

See: https://creativecommons.org/licenses/by-nc-nd/2.0/

\title{
ERJournal
}

Education Reform Journal Volume 5 Number 2, 2020

e-ISSN: $2602-3997$

http://dx.doi.org/10.22596/erj2020.05.02.60.77

\section{The Relationship Between Secondary Schools Students' Perceptions of School Climate, Their School Belonging And Their Academic Achievement}

\author{
Seva DEMIROZ ${ }^{1}$
}

Submitted: March 11, 2020; Accepted: November 30, 2020; Published Online: December 31, 2020

\begin{abstract}
The aim of this study is to examine the relationship between secondary school students' perceptions of school climate, their school belonging and their academic achievement. This descriptive study uses the correlational survey model. The participants were 340 sixth and seventh graders at a secondary school in the 2007-2008 academic year. To this end, the students were administered the School Climate Scale and the School Belonging Scale, and the average of their first term grades was used as a measure of academic achievement. This study found no significant difference between the students' perceptions of school climate and their school belonging by gender and grade. However, a significant difference was found between the students' perceptions of school climate and their school belonging, and their perceptions of school climate, school belonging and their academic success.
\end{abstract}

Keywords: School Climate, School Belonging, Academic Success

\section{Introduction}

Schools provide education and training. Students spend critical years in school to prepare for social life. Schools have an important place in the quality of education. A number of variables affect their quality, including school climate and school belonging. The concept of school climate (Hoy, 2003; Wang \& Degol, 2016) describes the quality and the characteristics of school life (Cohen, Mccabe, Michelli \& Pickeral, 2009). Although there is no consensus on its definition (Cohen et. al, 2009; Wang \& Degol, 2016), it is agreed that school climate is multidimensional and includes physical, social and academic aspects (Loukas, Suzuki \& Horton, 2006) and that it has a complex structure (Marshall, 2004; Suldo, McMahan, Chappel \& Loker, 2012). Briefly, school climate can be described as school characteristics and quality. It is based on the common perceptions of the people in the school and the influences of all their behaviors, and it is relatively continuous. School climate involves all the inner features that differentiate one school from another and affect the behavior of the people in the school (Hoy \& Miskel, 2012). Even if schools have similar physical structures, each school is a unique social organism with a unique atmosphere. As opposed to personality for individuals, schools have atmosphere or climate

${ }^{1}$ Ari Okullari, [0000-0001-7099-263X], sevademiroz@ hotmail.com 
(Bursalioglu, 2015). In other words, school climate can vary from one school to another. The physical characteristics of school, the quality of social relations, the demographic and cultural backgrounds of students, teachers, administrators and other employees, shared norms and values all affect school climate. According to Norton (1984), school climate plays an important role in identifying the current and future situations of schools. Studies of school climate are valuable because they collect information that can help scholars to understand and improve schools (Anderson, 1982). Improving school climate affects the quality of school practices and make schools successful (Sandy, Kimberlee, Cassandra \& Robinson, 2007). According to Cohen et. al (2009), school climate describes the quality and characteristics of school life and affects school culture.

The culture of a school can impact students' academic performance positively, which accordingly affects whether the school is effective. Effective schools support their students' emotional, cognitive, social, aesthetic and psychomotor development with the most appropriate learning environments (Cohen et. al., 2009; Ozdemir, 2012; Faour, 2012). Effective schools are the schools that use educational tools, appropriate physical environments and other resources effectively (Gonder \& Hymes, 1994; Ozdemir \& Sezgin, 2002). Educational institutions, which have an important role in the future of individuals and countries, must develop a strong and positive school climates in order to meet these expectations (Okcu, 2008). Creating an effective educational environment depends on school climate. Effective educational environments do not happen by coincidence. The relations between people and school climate differ from other organizations because they are less formal and more natural (Acikalin, 1994). Although changes are suggested for the improvement of schools, it is not possible to improve them without creating a positive school climate (Balci, 2007).

Undoubtedly, school climate affects students most. School climate includes both positive and negative aspects of the schools. Its positive aspects include being interested, academic development, solidarity, social development, communication and participation opportunities. Its negative aspects are communication disorders, hostile attitudes, the negative qualities of teachers, resistance to change, disregarding needs and arbitrary decision making (Ellis, 1988; Ozdemir, Sezgin, Sirin, Karip \& Erkan, 2010). The different levels of academic achievement in schools, which looks almost identical from an external perspective can explained by the fact that they have different school climates. A positive school climate increases student success reduces disciplinary problems (Mitchell, Bradshaw \& Leaf, 2010) and makes students become enthusiastic and hardworking. A negative school climate causes student to become estranged and affects their attitudes towards school negatively (Ellis, 1988). The most striking result of the studies of school climate is that negative school climate reduces students' academic achievement (Sweetland \& Hoy, 2000). Lubienski, Lubienski \& Crane (2008) found that positive school climate, teachers are satisfied with their jobs, and their organizational commitment and feelings of solidarity increase. All these positive outcomes are reflected in students' performance. School climate affects the relationships among the individuals in schools, creates commitment among students and raises academic achievement. Booker (2004) also found that a negative school climate lowers students' academic achievement, and negatively affects their adaptation to school, peer relationships, embracing of school and school belonging.

School belonging is defined by Goodenow \& Grady (1993) as students' acceptance as individuals in the social environment of the school and getting respect and support from other students. Booker (2004) defines it as students' feeling like important and valued members of the school community. O'Neill 
(2009) defines school belonging as experiences that make students feel valued and important. School belonging means that students feel like meaningful, important and valued members of the school community (Arslan \& Duru, 2017; Osterman 2000). School belonging can thus be defined as students' perceptions of being respected, accepted and seen as adding value to the school by all the other people in the school, with all their pros and cons or successes and failures. School belonging refers to the feelings and thoughts of students, the main actors in schools, about their schools, their school experiences and their roles.

Considering that students spend much of their time in school, supportive and safe school environments will increase their school belonging. Students' sense of belonging to social groups causes them to develop positive attitudes towards schools and want to protect and improve them. Students with a strong sense of belonging feel valued, have high self-esteem, and their communication with their peers and trust in the school increase (Ozdemir et al., 2010). As students' school belonging increases, their attendance and preparedness for school also increase (Finn, 1989). Students with a strong commitment to their schools also have higher levels of compliance with school and classroom rules, and participation in social activities and academic work (Adelabu, 2007).

Positive, constructive attitudes and behaviors that conform to school rules lead to positive school environments and school climates that support versatile development. In the media, unfortunately, school have recently begun to be associated with violence. To understand and resolve these negative behaviors, the concept of school belonging has begun to be emphasized. Students who do not feel a sense of school belonging become estranged from their schools. As school belonging decreases, problem behaviors and dropouts increase. If students do not feel school belonging, they adopt antisocial behavior patterns. Thus, developing school belonging can help to solve many of schools' problems. If the need for school belonging cannot be met at school, students try to meet these needs by belonging to gangs. This can also lead to alcohol and drug addiction.

Schools are social structures. For this reason, students need to experience the feeling of belonging, just like individuals and groups in social life. If people feel like they belong to a group or community, they feel safe and make progress. They also protect their communities and contribute to their development. This relationship is bidirectional. The sense of belonging is both a sociological and psychological concept. It is a basic psychological need. In Maslow's hierarchy of needs, individuals tend to meet their higher-level needs after meeting their physiological needs. They interact with other members of their society in various environments to meet needs such as loving, being loved and belonging (Yazgan, Inanc \& Yerlikaya, 2010). The sense of belonging is related to the need to be accepted and approved of by society. Academic achievement is associated with school belonging. Academic achievement is grade point average, engaging in expected behaviors and meeting criteria (Duru \& Balkis, 2015). Roeser, Midgley \& Urdan (1996) reported that school belonging is related to academic achievement, academic performance, enhanced motivation and self-efficacy.

Individual factors such as interest, ability, value, intelligence and motivation and environmental factors such as learning environments and physical conditions affect academic success. Harmony between individual and environmental factors increases academic success. As an environmental factor, positive school climate positively affects both academic success and school belonging. 
Pittman \& Richmond (2008) examined the relationship between school belonging and academic achievement and found a positive relationship between school belonging and academic achievement. The students' sense of belonging to their university was a significant predictor of their academic achievement. Similarly, in another study conducted with university students, Anderson (2010) found that school belonging was positively related to students' academic achievement. Other studies also have found that besides academic achievement, there is a direct relationship between school belonging and class attendance, preparing for school, doing homework, and active participation in social and sports activities.

The concept of school climate, which is the focus of this study, is very important for the field of education management in terms of students' academic achievement and school belonging. If school climate is constructive, and the students' relationships are not threatening to each other, school belonging can develop. In this perspective, identifying the variables that predict students' perceptions about school climate and increase their school belonging is thus of great importance.

\section{Research Questions}

The aim of this study is to examine the relationship between secondary school students' perceptions of school climate, their school belonging and their academic success. Accordingly, the following research questions were formulated:

1. What are the students' perceptions of school climate? Do their perceptions vary by gender and grade?

2. What are the students' feelings of school belonging? Do their feelings vary by gender and grade?

3. Is there any relationship between the students' perceptions of school climate and their academic achievement?

4. Is there any relationship between the students' school belonging and their academic achievement?

5. Is there any relationship between the students' perceptions of school climate and their school belonging?

\section{Research Method}

\section{Design}

This study used the correlational survey model to determine the relationship between the secondary school students' perceptions of school climate, their school belonging and academic achievement. According to Karasar (2003), studies that use the correlational survey model are intended to determine the existence or degree of change in the interaction between two or more variables. This study examines the relationships between secondary school students' perceptions of school climate, their school belonging and academic achievement, and compares them by gender and grade.

\section{Participants}

The participants were 340 sixth and seventh graders at a secondary school in the 2007-2008 academic year. Descriptive statistics related to their gender and grade are shown in Table 1. 
Demiroz (2020). Education Reform Journal, 2020, 5(2), 60-77

Table 1

The Distribution of the Students by Gender and Grade

\begin{tabular}{lcc}
\hline Gender & $\mathbf{n}$ & $\mathbf{\%}$ \\
\hline Female & 171 & 50.3 \\
\hline Male & 169 & 49.7 \\
\hline Total & $\mathbf{3 4 0}$ & $\mathbf{1 0 0}$ \\
\hline Grade & $\mathbf{n}$ & $\mathbf{\%}$ \\
\hline $6^{\text {th }}$ grade & 176 & 51.8 \\
\hline $7^{\text {th }}$ grade & 164 & 48.2 \\
\hline Total & $\mathbf{3 4 0}$ & $\mathbf{1 0 0}$ \\
\hline
\end{tabular}

Of this study's participants, $50.3 \%$ were female, and $49.7 \%$ were male. Of them, $51.8 \%$ were in sixth grade, and $48.2 \%$ were in seventh grade. The sample was homogenous in terms of gender and grade.

\section{Instruments}

The students were administered the School Climate Scale and the School Belonging Scale. They filled these scales in their class time under the supervision of their teachers. The teachers were instructed before they administered the scales. The participants were informed that they could quit filling out the scales whenever they wished. It took approximately 20-25 minutes to complete the scales. The students' first term grade average was used as a measure of their academic achievement.

\section{The School Climate Scale (SCS)}

The School Climate Scale developed by Calik \& Kurt (2010) is a 5-point Likert-type scale consisting of 22 items. This scale is a measurement tool that can be used to understand school climate from students' perspective. The grading scale was designed as never $=1$ and always $=5$. Exploratory factor analysis determined that the scale consists of three factors: supportive teacher behaviors (our teachers make the classroom environment fun, 8 items), success orientation (we spend all our energy on activities we perform in the classroom, 4 items), and safe learning environment and positive peer interaction (I am happy to be in the same class as my classmates, 10 items). In the three-factor structure, the factor load values of the items range between .45 and .85 . The Cronbach's alpha internal consistency coefficients of the subdimensions of the scale were $.69, .81$ and .83 . The Cronbach's alpha internal consistency coefficient of the entire scale was .81 . The School Climate Scale's subdimensions, items and Cronbach's alpha coefficients are shown in Table 2. 
Demiroz (2020). Education Reform Journal, 2020, 5(2), 60-77

Table 2

The School Climate Scale's Subdimensions, Items and Cronbach's Alpha Coefficients

Subdimensions

Supportive teacher behaviors (support)

Success orientation (success)

Safe learning environment and positive peer interaction (trust)
Number of items Items Cronbach's $\alpha$

Scale items 13, 14, 16, 18, 19, 21 and 22 are reverse coded because they are negative statements. The items are scored: always $=5$, mostly $=4$, occasional $=3$, rarely $=2$, and never $=1$. Thus, the highest possible score is 110 , and the lowest is 22 . Personal questions were added to the scale in order to obtain personal information from the students.

\section{The School Belonging Scale (SBS)}

The School Belonging Scale developed by Akar-Vural, Yilmaz-Ozelci, Cengel \& Gomleksiz (2013) is a 5-point Likert-type scale with 10 items. This scale is used to determine students' school belonging. The rating scale was created as I strongly disagree $=1$ and I strongly agree $=5$. The scale consists of two subdimensions: school satisfaction ( 5 items) and school rules ( 5 items). The factor loads of the items in each factor ranged between .68 and .86, and the item-factor correlation coefficients ranged between .57 and .75 . For the subdimensions of the scale, the Cronbach's alpha internal consistency coefficients were .86 and .79. For the entire scale, the Cronbach's alpha internal consistency coefficient was .88. Its number of items in the subdimensions, the internal consistency coefficients, arithmetic means and standard deviation values are shown in Table 3.

Table 3

\section{School Belonging Subdimensions}

\begin{tabular}{lcccc}
\hline Subdimensions & Number of items & $\begin{array}{l}\text { Cronbach's } \\
\boldsymbol{\alpha}\end{array}$ & Mean & $\begin{array}{l}\text { Standard } \\
\text { Deviation }\end{array}$ \\
\hline School satisfaction & 5 & .86 & 4.38 & 0.98 \\
\hline Compliance with school rules & 5 & .79 & 4.21 & 1.44 \\
\hline
\end{tabular}


Demiroz (2020). Education Reform Journal, 2020, 5(2), 60-77

\section{Academic Achievement}

The sixth and seventh graders' average grades in mathematics, Turkish, science and technology, and social studies in the first semester of 2017-2018 academic year were used as a measure of their academic achievement. The results are shown in Table 4.

\section{Table 4}

The Students' Academic Achievement

\begin{tabular}{ccc}
\hline $\mathbf{n}$ & $\overline{\mathbf{x}}$ & sd. \\
\hline 340 & 92.12 & 7.08 \\
\hline
\end{tabular}

The students' first term academic averages were quite high.

\section{Findings}

What are the students' perceptions of school climate? Do they vary by gender and grade?

The students' perceptions of school climate were shown in Table 5. The independent samples ttest was used to compare their perceptions of school climate by gender and grade.

Table 5

Independent Samples t-test Results for the Students' Perceptions of School Climate by Gender and Grade

\begin{tabular}{lccccc}
\hline Groups & $\mathbf{N}$ & $\overline{\mathbf{x}}$ & $\mathbf{S s}$ & $\mathbf{T}$ & $\mathbf{P}$ \\
\hline Female & 172 & 3.89 & .473 & 1.96 & .164 \\
\hline Male & 168 & 3.77 & .567 & & \\
\hline $6^{\text {th }}$ grade & 176 & 3.90 & .527 & 2.58 & .645 \\
\hline $7^{\text {th }}$ grade & 164 & 3.76 & .514 & & \\
& & & & & \\
\end{tabular}


The students' perceptions of school climate did not vary significantly by gender or grade $[\mathrm{t}=1.96$, $\mathrm{p}<.05 ; \mathrm{t}=2,582, \mathrm{p}<.05]$. The means for the male and female students' school climate perceptions were $\overline{\mathrm{x}}=3.89$ and $\overline{\mathrm{x}}=3.77$, respectively, which were close to the mostly range. Table 5 shows that the perceptions of school climate means were $\bar{x}=3.90$ for the sixth graders and $\bar{x}=3.76$ for the seventh graders. These were close to the mostly range on the 5-point Likert scale. The students' perceptions of school climate were above the medium level. The lack of significant difference in the students' perceptions of school climate according to gender or grade $[\mathrm{t}=1.96, \mathrm{p}<.05$; the absence of $\mathrm{t}=2,582, \mathrm{p}<.05]$ indicated that the students' thought the school climate was medium and close to good.

What are the students' feelings of school belonging? Do they vary by gender and grade?

The students' feelings of school belonging were shown in Table 6. The independent samples t-test was used to compare the students' school belonging by gender and grade.

\section{Table 6}

Independent Samples t-test Results for the Students' School Belonging by Gender and Grade

\begin{tabular}{lccccc}
\hline Groups & $\mathbf{N}$ & $\overline{\mathbf{x}}$ & $\mathbf{s S}$ & $\mathbf{T}$ & $\mathrm{p}$ \\
\hline Female & 172 & 4.04 & .040 & 1.26 & .001 \\
\hline Male & 168 & 3.91 & .569 & & \\
\hline Sixth grade & 176 & 3.97 & .537 & & -.388 \\
\hline Seventh grade & 164 & 3.99 & .573 & & .957 \\
\hline School belonging & 340 & 3.98 & .554 & & \\
\hline
\end{tabular}

The students' sense of school belonging varied significantly by gender $[t=1.26, p<.05]$. The means for the male and female students' school belonging were $(\overline{\mathrm{x}}) 4.0=4.04$ and $(\overline{\mathrm{x}})=3.91$, respectively, which were within the "I agree" range on the 5-point Likert scale. Female students rated their school belonging significantly higher than their male counterparts. However, there was no significant differences between $6^{\text {th }}$ and $7^{\text {th }}$ graders regarding school belonging [t=-.388, $\left.\mathrm{p}>.05\right]$. Table 6 showed that the school belonging means were $(\bar{x})=3.97$ for the sixth graders and $(\bar{x})=3.99$ for the seventh graders. These were within the "I agree" range on the 5-point Likert scale. The students thus had a strong sense of school belonging. The lack of a significant difference in the students' school belonging by gender or grade $[t=1.96, p<.05$; the absence of $t=2,582, p<.05]$ indicated that their school belonging is positive irrespective of gender or grade.

Is there any relationship between the students' perceptions of school climate and their academic achievement? 
Demiroz (2020). Education Reform Journal, 2020, 5(2), 60-77

Spearman's correlation coefficient was used to determine the relationship between the students' perceptions of school climate and their academic success. The results were shown in Table 7.

\section{Table 7}

The Relationship Between the Students' Perceptions of School Climate and Their Academic Achievement

\begin{tabular}{lllll}
\hline Variable & $\mathrm{N}$ & $\mathrm{r}$ & $\mathrm{r}^{2}$ & $\mathrm{p}$ \\
\hline Perceptions of school climate & & & & \\
& 340 & .520 & .27 & .000
\end{tabular}

Academic achievement

Table 7 showed that there was a significant relationship between the students' perceptions of school climate and their academic achievement. This relationship was positive and moderate $(\mathrm{r}=.52$, $\mathrm{p}<.01)$. The determination coefficient $\left(\mathrm{r}^{2}=0.27\right)$ indicated that the students' perceptions of school climate and their academic achievement explained each other by $27 \%$.

Is there any relationship between the students' school belonging and their academic achievement?

Spearman's correlation coefficient was used to determine the relationship between the students' school belonging and their academic achievement. The results are shown in Table 8.

\section{Table 8}

\section{The Relationship Between the Students' School Belonging and Their Academic Achievement}

\begin{tabular}{lcccc}
\hline Variable & $\mathrm{N}$ & $\mathrm{R}$ & $\mathrm{r}^{2}$ & $\mathrm{P}$ \\
\cline { 1 - 2 } School belonging & & & & \\
\hline $\begin{array}{l}\text { Academic } \\
\text { achievement }\end{array}$ & 340 & .720 & .518 & .000 \\
\hline
\end{tabular}

Table 8 showed that there was a significant relationship between the students' school belonging and their academic achievement. This relationship was positive and strong $(r=.72, p<.01)$. The determination coefficient $\left(r^{2}=0.518\right)$ indicated that the students' school belonging and their academic achievement explained each other by $52 \%$.

Many studies found positive relationships between students' school belonging and their academic achievement (Adelabu, 2007; Anderman, 2002; Booker, 2004; Goodenow, 1992a, 1992b, 1993). Studies 
also found that students who feel that they love and belong to their schools have higher academic achievement and lower dropout rates, absenteeism and discipline problems than the students who do not. One important predictor of school climate and school belonging is students' academic achievement. Tables 8 and 9 showed that positive school climate and a strong sense of school belonging increased the students' academic success. This finding was compatible with some research results in the literature (Heck, 2009; Turan, 1998). Studies emphasized that it was easier for students to engage in academic achievement-oriented behaviors in a positive school climate. Schools should provide a positive, safe and appropriate learning environment for their students to ensure their academic, emotional and behavioral development (Blum, 2005).

Is there any relationship between the students' perceptions of school climate and their school belonging?

Spearman's correlation coefficient was used to determine the relationship between the students' perceptions of school climate and their school belonging. The results were shown in Table 9 .

\section{Table 9}

The Relationship Between the Students' Perceptions of School Climate and Their School Belonging

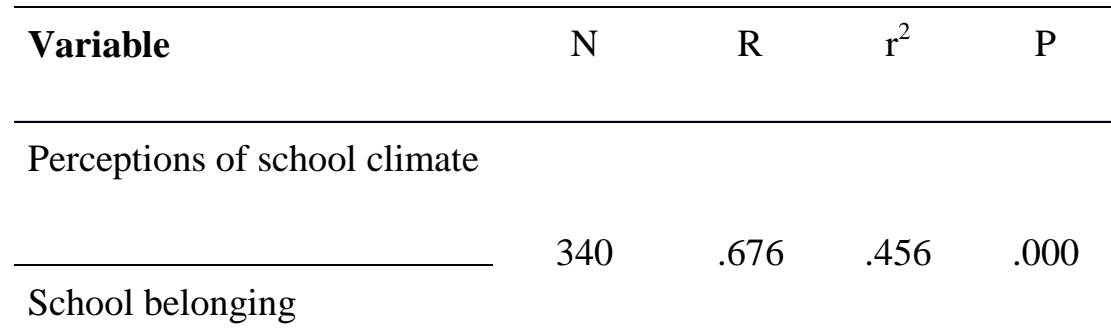

Table 9 showed that there was a significant relationship between the students' perceptions of school climate and their school belonging. This relationship was positive and high $(\mathrm{r}=.676, \mathrm{p}<.01)$. Considering the determination coefficient $\left(r^{2}=0.45\right)$, the students' perceptions of school climate and their school belonging explained each other by $45 \%$. This study's results showed that the students' feeling that they belonged and were loyal to the school affected their school belonging positively.

\section{Discussion}

School climate was investigated with different variables over the decades. Some of the researchers grouped factors related to school climate and study each concept to identify the causes, effects and relationship (Griffith, 1999, 2000; Vieno et al., 2005). This current study analyzed school climate in relation to gender, grade, school belonging and academic achievement.

No significant difference was found between the students' perceptions of school climate by grade and gender. Since the age and grade level gap of 6th and 7th graders were close to each other, a difference might not occur. However, gender was reported to be significantly associated with perceptions of school 
climate, with male students tending to perceive the environment less favorably (Battistich et al., 1995; Griffith, 1999, 2000; Kuperminc et al., 2001, 1997; Verkuyten \& Thijs, 2002; Welsh, 2000). Although studies were tended to report more favorable perceptions of school climate among females, (e.g., Fan et al., 2011; Koth, Bradshaw, \& Leaf, 2008; Verkuyten \& Thijs, 2002), some studies indicated the opposite (e.g., Mitchell, Bradshaw, \& Leaf, 2010). In this current study both female and male students perceived support, success and trust dimension of the school climate almost around the same level. The reason could be further studied.

A significant difference was found between the students' perceptions of school belonging by gender. Female students reported their belonging higher than male students. It could be that male students inclined to less order and discipline at school. This might impact their compliance with school rules and then school belongings (Lahey et al., 2000; McDermott, 1996; Putallaz \& Bierman, 2004; Roberts \& Baird, 1972; Tremblay et al., 1996).

A significant relationship was found between the students' perceptions of school climate and their academic achievement. This relationship was positive and moderate $(r=.52, \mathrm{p}<.01)$. Prior research supported this result (Goddard et al., 2000b; Heck, 2000; Thapa et al., 2013). Empirical evidence confirmed that school climate was powerful in affecting students' academic achievement (Brand et al., 2008; Chen \& Weikart, 2008; Collins and Parson, 2010). An adverse school climate was found to reduce student participation in school activities and learning processes (Chen \& Weikart, 2008). Some research in the field reported that school climate perception did not significantly impact reading performance (Ma and Klinger, 2000; Reynolds et al., 2017). However, in general school climate-achievement association featured to be robust for students across different grades, backgrounds, and cultures (Gregory et al., 2007; Jia et al., 2009).

A significant relationship was found between the students' school belonging and academic achievement. This relationship was positive and strong $(\mathrm{r}=.72, \mathrm{p}<.01)$. Moreover, a significant relationship was found between the students' perceptions of school climate and their school belonging. This relationship was positive and strong $(\mathrm{r}=.676, \mathrm{p}<.01)$. Some of the previous studies in the field reported similar findings (Brand, Felner, Shim, Seitsinger, \& Dumas, 2003; Waters, Cross, \& Runions, 2009). For example, Benner, Graham, \& Mistry (2008) posited that perceptions of school climate and school belonging were associated to students' engagement and academic success. Huang et al. (2013) reported that the correlation between school climate and school belonging was positive and significant. Understanding students' ratings of school climate and school belonging has been important, because these indicators could assist schools to evaluate their effectiveness, students' learning achievement and where they should improve.

\section{Conclusion and Recommendations for Future Research}

A direct implication of this research is that researchers, principals, and policy makers could have new insights into relationship among school climate, school belonging, academic achievement, gender and grade level. One of the important messages could be that strengthening students' perception of school climate and school belonging is important in improving learning. Although perception of school climate among the students was not different in this study, male students rated their school belongings lower than 
female students. Both practitioners and researchers could plan actions to enhance students, especially male students, school belongings through the use of a process which their views are valued and respected (Haslam, Eggins, \& Reynolds, 2003; Tyler \& Blader, 2000).

Qualitative research methods such as observation, interviews and document analysis could be utilized to understand students' perceptions of school climate in depth. It may be possible to determine the activities and arrangements that contribute to positive school climate through interviews with students. Studies conducted with larger sample sizes and different grades can also provide more insight into the different levels of students' perceptions of school climate.

The relationships between variables that may influence different grade of students' perceptions of school climate and their school belonging (academic achievement, absenteeism, discipline problems, teacher attitudes, socio-economic levels, etc.) should be examined in larger samples using procedural techniques.

Since this study was conducted using the correlational survey model, it emphasized mutual relations rather than cause and effect relationships. Further studies of the cause-and-effect relationships between students' perceptions of positive school climate and their academic achievement, their school belonging and academic achievement, and their perceptions of school climate and school belonging could be conducted.

\section{Acknowledgements}

None. No funding to declare.

\section{Conflict of Interest}

Author has no conflict of interest to report. 
Demiroz (2020). Education Reform Journal, 2020, 5(2), 60-77

\section{References}

Acikalin, A. (1994). Teknik ve Toplumsal Yonleriyle Okul Yoneticiligi. Ankara: PEGEM Yayin No: 10.

Adelabu, D. D. (2007). Time perspective and school membership as correlates to academic achievement among African American adolescents. Adolescence, 42(167), 525-538.

Akar-Vural, R., Yilmaz-Ozelci, S., Cengel, M. \& Gomleksiz, M. (2013). The development of the "Sense of belonging to school" Scale. Eurasian Journal of Educational Research. 53, 215-230.

Anderman, E. M. (2002). School effects on psychological outcomes during adolescence. Journal of Educational Psychology, 94, 795-809.

Anderson, C. M. (2010). Linking perceptions of school belonging to academic motivation and academic achievement amongst student athletes: A comparative study between High Revenue Student Athletes and Non-Revenue Student Athletes. (Unpublished_Dissertation). University of California, California, USA.

Anderson, C. S. (1982). The search for school climate: A review of research. Review of Educational Research, 52(3), 368-420.

Arslan, G. \& Duru, E. (2017). Initial development and validation of the school belongingness Scale. Child Indicators Research, 10(4), 1043-1058.

Balci, A. (2007). Etkili Okul ve Okul Gelistirme: Kuram, Uygulama ve Arastirma. Ankara: Pegem Akademi.

Battistich, V., Solomon, D., Kim, D., Watson, M., \& Schaps, E. (1995). Schools as communities, poverty levels of student populations, and students' attitudes, motives, and performance: A multilevel analysis. American Educational Research Journal, 32, 627-658.

Benner, A. D., Graham, S., \& Mistry, R. S. (2008). Discerning direct and mediated effects of ecological structures and processes on adolescents' educational outcomes. Developmental Psychology, 44(3), 840-854.

Blum, R. (2005). School connectedness: Improving the lives of students. Baltimore, Maryland: Johns Hopkins Bloomberg School of Public Health.

Booker, C., K. (2004). Exploring school belonging and academic achievement in African American adolescent. Curriculum and Teaching Dialogue, 6(2), 131- 143.

Brand, S., Felner, R. D., Seitsinger, A., Burns, A., and Bolton, N. (2008). A large scale study of the assessment of the social environment of middle and secondary schools: the validity and utility of teachers' ratings of school climate, cultural pluralism, Journal of School Psychology. 46, 507-535. doi: $10.1016 /$ j.jsp.2007.12.001

Brand, S., Felner, R., Shim, M., Seitsinger, A., and Dumas, T. (2003). Middle school improvement and reform: development and validation of a school-level assessment of climate, cultural pluralism, and school safety. Journal of Educational Psychology. 95:570. doi: 10.1037/0022-0663.95.3.570 
Demiroz (2020). Education Reform Journal, 2020, 5(2), 60-77

Bursalioglu, Z. (2015). EgitimYonetiminde Yeni Yapi ve Davranis. 19. Baski. Pegem Akademi Yayincilik. Ankara.

Chen, G., \& Weikart, L. A. (2008). Student background, school climate, school disorder, and student achievement: an empirical study of New York City's middle schools. Journal of School Violence, 7, 3-20. doi: 10.1080/15388220801973813

Cohen, J., Mccabe, E.M., Michelli, N. M. \& Pickeral, T. (2009). School climate: Research, policy, practice, and teacher education. Teachers College Record, 111 (1), 180-213.

Collins, T. N., \& Parson, K. A. (2010). School climate and student outcomes. Journal of CrossDisciplinary Perspectives in Education. 3, 34-39.

Calik, T. \& Kurt, T. (2010). Development of the school climate scale. Education and Science, 157(35), 167-180.

Duru, E. \& Balkis, M. (2015). The Analysis of Relationships between Person-Environment Fit, Sense of Belongingness, Academic Satisfaction and Academic Achievement. Ege Education Journal, 16(1), $122-141$.

Ellis T.I. (1988). School climate. Research Roundup, 4(2), 1-6.

Fan, W., Williams, C. M., \& Corkin, D. M. (2011). A multilevel analysis of student perceptions of school climate: The effect of social and academic risk factors. Psychology in the Schools, 48, 632e647. http://dx.doi.org/10.1002/pits.20579.

Faour M. (2012). The Arab world's education report card: School climate and citizenship skills. Washington, DC: Carnegie Endowment for International Peace.

Finn, J. D. (1989). Withdrawing from school. Review of Educational Research, 59(2), 117- 142.

Goddard, R. D., Sweetland, S. R., and Hoy, W. K. (2000b). Academic emphasis of urban elementary schools and student achievement in reading and mathematics: a multilevel analysis. Educational Administration Quarterly. 36, 683-702. doi: 10.1177/00131610021969164

Godeneow, C. (1992a). Strengthening the links between educational psychology and the study of social contexts. Educational Psychologist, 27(2), 177-196.

Goodenow, C. (1992b, April). School motivation, engagement, and sense of belonging among urban adolescent students. Paper presented at the Annual Meeting of the American Educational Research Association, San Francisco, CA.

Goodenow, C. (1993). The psychological sense of school membership among adolescents: Scale development and educational correlates. Psychology in the Schools, 30, 79-90

Goodenow, C., \& Grady, K. E. (1993).The relationship of school belonging and friends' values to academic motivation among urban students. The Journal of Experimental Education, 62(1), 60-71. 
Demiroz (2020). Education Reform Journal, 2020, 5(2), 60-77

Gonder P.O. \& Hymes D. (1994). Improving school climate and culture. (AASA Critical Issues Report No. 27) Arlington, VA: American Association of School Administrators.

Gregory, A., Henry, D. B., \& Schoeny, M. E. (2007). School climate and implementation of a preventive intervention. American Journal of Community Psychology. 40, 250-260. doi: 10.1007/s10464-0079142-z

Griffith, J. (1999). School climate as "social order" and "social action": A multi-level analysis of public elementary school student perceptions. School Psychology of Education, 2, 339-369.

Griffith, J. (2000). School climate as group evaluation and group consensus: Student and parent perceptions of the elementary school environment. Elementary School Journal, 101, 35-61.

Haslam, S. A., Eggins, R. A., and Reynolds, K. J. (2003). The ASPIRe model: actualizing social and personal identity resources to enhance organizational outcomes. Journal of Occupational and Organizational Psychology. 76, 83-114. doi: 10.1348/096317903321208907

Heck, R. H. (2000). Examining the impact of school quality on school outcomes and improvement: a value-added approach. Educational Administration Quarterly. 36, 513-552. doi: $10.1177 / 00131610021969092$

Heck, R. H. (2009). Teacher effectiveness and student achievement: Investigating a multilevel crossclassified model. Journal of Educational Administration, 47(2), 227-249.

Hoy, W.K. (2003). School climate. In J.W. Guhtrie (Ed.), Encylopedia of Education (2nd ed.), (pp. 21212124). New York: Thompson Gale.

Hoy, W. K., \& Miskel, C. G. (2012). Egitim Yonetimi: Teori, Uygulama ve Arastirma (Ed. \& Trans S. Turan). Ankara: Nobel

Huang, H., Xiao, L., Huang, D. (2013). Students' ratings of school climate and school belonging for understanding their effects and relationship of junior high schools in taiwan. Global Journal of Human Social Science Linguistics \& Education, 13(3). Version 1.

Jia, Y., Way, N., Ling, G., Yoshikawa, H., Chen, X., Hughes, D., et al. (2009). The influence of student perceptions of school climate on socioemotional and academic adjustment: a comparison of Chinese and American adolescents. Child Development. 80, 1514-1530. doi: 10.1111/j.14678624.2009.01348.x

Karasar N. (2003). Bilimsel Arastirma Yontemi. Ankara: Nobel Yayin Dagitim.

Koth, C. W., Bradshaw, C. P., \& Leaf, P. J. (2008). A multilevel study of predictors of student perceptions of school climate: The effect of classroom-level factors. Journal of Educational Psychology, 100, 96-104.

Kuperminc, G. P., Leadbeater, B. J., \& Blatt, S. J. (2001). School social climate and individual differences in vulnerability to psychopathology among middle school students. Journal of School Psychology, 39, 141- 159. 
Demiroz (2020). Education Reform Journal, 2020, 5(2), 60-77

Kuperminc, G. P., Leadbeater, B. J., Emmons, C., \& Blatt, S. J. (1997). Perceived school climate and difficulties in the social adjustment of middle school students. Applied Developmental Science, 1 , $76-88$.

Lahey, B. B., Schwab-Stone, M., Goodman, S. H., Waldman, I. D., Canino, G., Rathouz, P. J., Miller, T. L., Dennis, K. D., Bird, H. R., \& Jensen, P. S. (2000). Age and gender differences in oppositional behavior and conduct problems: A cross-sectional household study of middle child- hood and adolescence. Journal of Abnormal Psychology, 109, 488-503.

Loukas, A., Suzuki, R. \& Horton, K.D. (2006). Examining school connecyedness as a mediator of school climate effects. Journal of Research on Adolesence, 16 (3), 491- 502. http://onlinelibrary.wiley.com/doi/10.1111/j.1532- 7795.2006.00504.x/

Lubienski, S. T., Lubienski, C \& Crane, C. C. (2008). Achievement differences and school type: The role of school climate, teacher certification and instruction. American Journal of Education, 115, 97138.

Ma, X., \& Klinger, D. A. (2000). Hierarchical linear modelling of student and school effects on academic achievement. Canadian. Journal of Education. 25, 41-55. doi: 10.2307/1585867

Marshall, M. L. (2004). Examining school climate: Defining factors and educational influences. Retrieved (31/07/2017) from Georgia State University Center for Mitchell et al., 2010),

McDermott, P. A. (1996). A nationwide study of developmental and gender prevalence for psychopathology in children and adolescence. Journal of Abnormal Child Psychology, 24, 53-66.

Mitchell, M.M, Bradshaw, C.P., \& Leaf, P.J. (2010). Student and teacher perceptions of school climate: A multilevel exploration of patterns of discrepancy. Journal of School Health, 80, 6: 271-279.

Norton M. S. (1984). What is so important about school climate? Contemporary Education, 56, 43-45. http://education.gsu.edu/schoolsafety.

Okcu, V. (2008). Egitimde toplam kalite yonetiminin uygulanmasi. Millî Egitim, (179), 283-292.

O’Neill, F. K. (2009). Giving from our bodily belongings: Is donation an appropriate -paradigm for the giving of bodies and body parts? HEC Forum, 21(2), 151-174. doi:10.1007/s10730-009-9094-9

Osterman, F. K. (2000). Students' need for belonging in the school community. Review of Educational Research, 70(3), 323-367

Ozdemir, M. (2012). Examination of High School Students' Metaphorical School Perceptions in terms of Various Variables. Education and Science, 37(163), 96-109.

Ozdemir S. \& Sezgin F. (2002). Effective schools and instructional leadership. MANAS Journal of Social Studies, 2(3), 266-282.

Ozdemir,S., Sezgin, F., Sirin,H., Karip,E. \& Erkan S.(2010). Examining the variables predicting primary school students' perceptions of school climate. H. U. Journal of Education, 38 (2010), 213-224. 
Demiroz (2020). Education Reform Journal, 2020, 5(2), 60-77

Pittman, L. D. V. \& Richmond, A. (2008). University belonging and friendship quality during the transition to college: Links to self-perceptions and psychological symptoms. Journal of Experimental Education, 76, 343- 361.

Putallaz, M., \& Bierman, K. L. (2004). Aggression, antisocial behavior, and violence among girls: A developmental perspective. New York: Guilford Press.

Reynolds, K. J., Lee, E., Turner, I., Bromhead, D., \& Subasic, E. (2017). How does school climate impact academic achievement? An examination of social identity processes. School Psychology International. 38, 78-97. doi: 10.1177/0143034316682295

Roberts, J., \& Baird, J. T. (1972). Behavior patterns of children in school. Vital and health statistics (DHEW Pub. No. HSM 72-1042). Washing- ton, DC: U.S. Government Printing Office.

Roeser, R.,W., Midgley, C., \& Urdan, T., C. (1996). Perceptions of the school psychological environment and early adolescents' psychological and behavioral functioning in school: The mediating role of goals and belonging. Journal of Educational Psychology, 88 (3), 408-42.

Sandy, W. Kimberlee, J. S., Cassandra, M.C. ve Robinson, J. (2007). Improving school climate and student behavior: A new paradigm for Indiana schools. Center for Evaluation and Education Policy, 5(9), 8p. www.eric.ed.gov/ERICWebPortal/search 09.11.2010.

Suldo, S. M., McMahan, M.M., Chappel, A. M. \& Loker, T. (2012). Relationships between perceived school climate and adolescent mental health across genders. School Mental Health, 4, 69-80. Doi: 10.1007/s12310-012-9073-1

Sweetland S.R. \& Hoy, W.K. (2000). School characteristics and educational outcomes: toward an organizational model of student achievement in middle schools. Educational Administration Quarterly, 36(5), 703-729.

Thapa, A., Cohen, J., Guffey, S., and Higgins-D’Alessandro, A. (2013). A review of school climate research. Review of Educational Research. 83, 357-385. doi: 10.3102/0034654313483907

Tremblay, R. E., Boulerice, B., Harden, P. W., McDuff, P., Perusse, D., Pihl, R. O., \& Zoccolillo, M. (1996). Do children in Canada become more aggressive as they approach adolescence? In Growing up in Canada (pp. 127-137). Ottawa: Statistics Canada.

Turan, S. (1998). Measuring Organizational Climate and Organizational Commitment in the Turkish Educational Context. Paper presented an the University Counsil for Educational Administration's Annual Meeting. October 29-Nowember 1, 1998, St. Louis, Missouri, USA. (ERIC NO: ED429359),

Tyler, T. R., \& Blader, S. L. (2000). Cooperation in groups: Procedural justice, social identity and behavioral engagement. Philadelphia, PA: Psychology Press.

Verkuyten, M., \& Thijs, J. (2002). School satisfaction of elementary school children: The role of performance, peer relations, ethnicity and gender. Social Indicators Research, 59, 203-228. 
Demiroz (2020). Education Reform Journal, 2020, 5(2), 60-77

Vieno, A., Perkins, D. D., Smith, T. M., \& Santinello, M. (2005). Democratic school climate and sense of community in school: A multilevel analysis. American Journal of Community Psychology, 36, 327341.

Wang, M.T. \& Degol, J. L. (2016). School climate: a review of the construct, measurement, and impact on student outcomes. Educational Psychology Review, 28, 315-352. Doi: 10.1007/s10648-0159319-1

Waters, S. K., Cross, D. S., and Runions, K. (2009). Social and ecological structures supporting adolescent connectedness to school: a theoretical model. Journal of School Health 79, 516-524. doi: 10.1111/j.1746-1561.2009.0 0443.x

Welsh, W. N. (2000). The effect of school climate on school disorder. Annals of the American Academy of Political and Social Sciences, 567, $88-107$.

Yazgan, I. B. \& Yerlikaya, E .E. (2010). Kisilik Kuramlari. (3.Baski). Ankara: Pegem Akademi Yayinevi. 